\section{Performance of 15 Exacum affine Genotypes in a Low-irradiance Environment}

\author{
David B. Rubino \\ U.S. Department of Agriculture, Agricultural Research Service, Florist \\ and Nursery Crops Laboratory, Beltsville, MD 20705-2350
}

Additional index words. Persian violet, simulated home environment, genotypic variability, postharvest

Abstract. Fifteen cultivated genotypes of Exacum affine Balf. were evaluated for flower development and for flower and leaf color at 0 days (marketable stage, $\approx 25 \%$ of plant canopy covered with flowers), and after 14 and 28 days of maintenance in a lowirradiance environment $\left(\approx 1 \mu \mathrm{mol} \cdot \mathrm{m}^{-2} \cdot \mathrm{s}^{-1}\right.$ photosynthetically active radiation from cool-white fluorescent lights for 12 hours daily). Flowering and flower color development were reduced, but leaf color improved during maintenance under low irradiance. Variability was observed among the $\mathbf{1 5}$ genotypes for flower bud and flower color development in a low-irradiance environment.
Consumers desire flowering potted plants that maintain their showiness after being transported, displayed under retail conditions, and placed in the home or office environment (Shafer and Kelly, 1986). Both the plant species and cultivar can affect interior performance (Nell and Barrett, 1986).

Exacum affine (Persian violet) has a long postharvest life (Irwin, 1979, Larson, 1981). Harbaugh and Waters (1979) evaluated 53 cultivars representing 21 genera of flowering potted plants under simulated home or office conditions ( 23 to $26 \mathrm{C}, 1.2$ to $1.5 \mathrm{klx}$ from cool-white tubes with a 12 -h photoperiod). They reported that the performance of three $E$. affine cultivars during the first 4 weeks in simulated home conditions was as good as or better than that of Sinningia and Dendranthema grandiflora Tzvelev. (Chrysanthemum morifolium Ramat.) 'Puritan' plants used for comparison. However, flower color faded from violet to gray after 4 to 6 weeks. The postharvest performance of the three cultivars was similar.

Harbaugh and Waters (1982) showed that controlled-release fertilizer level at planting affected postharvest quality of $E$. affine 'Elfin' under simulated home conditions. An increase in fertilizer rate generally resulted in

Received for publication 15 Oct. 1990. Germplasm for this investigation was generously provided by Earl J. Small Growers, Pinellas Park, Fla., and by $\mathrm{J}$ and L Plants, Amarillo, Texas. Consultation with Robert Griesbach of the USDAARS Florist and Nursery Crops Laboratory, Beltsville, Md., is gratefully acknowledged. The financial assistance of the Fred C. Gloeckner Foundation is gratefully acknowledged. Mention of a trade name or proprietary product does not Dept. of Agriculture and does not imply approval to the exclusion of other products that may also be suitable. The cost of publishing this paper was defrayed in part by the payment of page charges. Under postal regulations, this paper therefore must be hereby marked advertisement solely to indicate this fact. constitute a guarantee or warranty by the U.S. less chlorosis, although it also resulted in a deterioration in floral display after 4 weeks under simulated home conditions.

Flower bud development in E. affine appears to depend on high irradiance levels (Irwin, 1984; Larson, 1981; Williams et al., 1983). We found no reports on the existence of genotypic variability for postharvest quality characteristics in cultivated $E$. affine germplasm. Therefore, this study was conducted to examine the effects of maintenance in a low-irradiance environment on $E$. affine flower development and new flower and leaf color and to determine if genotypic variability for these characteristics exists among a sample of cultivars and breeding lines.

Seedlings of 15 cultivars and breeding lines of $E$. affine (Table 1) were planted, one per 1.05-liter pot, in a soilless medium (Pro-mix BX, Premier Brands, Stamford, Conn.) supplemented with Micromax at $80 \mathrm{~g} \cdot \mathrm{m}^{-3}$ (fritted micronutrient mixture) and with $2 \mathrm{~g}$ of Osmocote 14N-6.1P-11.6K (controlled-release fertilizer) per pot. Pots were arranged in a randomized complete-block design with three blocks (glasshouses) and eight plants of each genotype per block. At the full bloom stage [ $\approx 25 \%$ of the plant canopy covered with flowers (L.T. Irwin, 1990, personal communication)], four plants of each genotype from each block were moved to a growth room maintained at $22.0 \pm 0.1 \mathrm{C}, 80 \%$ to $90 \%$ relative humidity, and $\approx 1 \mu \mathrm{mol} \cdot \mathrm{m}^{-2} \cdot \mathrm{s}^{-1}$ of photosynthetically active radiation (PAR) at plant level from Sylvania 60-W cool-white fluorescent lights for $12 \mathrm{~h}$ daily. The other
Table 1. Exacum affine genotypes and flower colors.

\begin{tabular}{ll}
\hline \hline Genotype & \multicolumn{1}{c}{ Flower color } \\
\hline Petite & Violet $(92 \mathrm{~A})$ \\
CE & Violet (92A) \\
Michigan White & White (155D) \\
3057A & Violet (93C) \\
42E & Violet (93C) \\
3033 & Violet (93C) \\
Royal Blue & Violet (93B) \\
4002A & White/rose (84C/155B) \\
Best Rosa & Rose (84C) \\
White Champion & White (155B) \\
Blue Champion & Violet (93C) \\
Little Champ & Violet (93C) \\
42Y & Violet (93C) \\
505 & Violet (93C) \\
Blue Chip & Violet (93C) \\
\hline
\end{tabular}

${ }^{2}$ Codes in parentheses are from the Royal Horticultural Society Colour Chart (1986).

"Genotype 4002A segregated for white and rose flower colors.

four plants were maintained during Apr. and May 1990 under natural irradiance ( $>5$ $\left.\mu \mathrm{mol} \cdot \mathrm{m}^{-2} \cdot \mathrm{s}^{-1} \mathrm{PAR}\right)$ in the glasshouse at 22.0 $\pm 2.0 \mathrm{C}$. Plants were watered when the soil was dry on the surface, at $\approx 3$-day intervals in the growth room and $\approx 2$-day intervals in the glasshouse. In both environments, the number of open flowers was counted at 0 , 14 , and 28 days, and color intensity was determined on two freshly opened flowers (with anthers just beginning to dehisce) and two fully expanded leaves by comparing them to the Royal Horticultural Society Colour Chart (1986). The color ratings were subsequently converted to a numerical scale by assigning values to panels of the color chart based on color intensity $(1=$ low intensity and $5=$ high intensity). Flower color was not evaluated for the genotypes with white flowers.

Flower count increased during maintenance in the growth room and glasshouse (Table 2). The response to days was significantly $(P<0.01)$ linear in both environments, although the response in the growth room was also nonlinear (Table 3). Therefore, the low-irradiance environment did not promote flower development. This result is consistent with Harbaugh and Waters (1982), whose report indicated a tendency for deterioration in floral display of plants maintained for 4 weeks under simulated home conditions for plants receiving overhead irrigation and similar rates of fertilizer application as in this study.

Flower color rating did not change during maintenance in the glasshouse but decreased in the growth room (Tables 2 and 3 ). The response to days of maintenance in the growth
Table 2. Mean values over genotypes and SD for three characteristics of Exacum affine for three intervals in the growth room (low irradiance) and glasshouse (high irradiance).

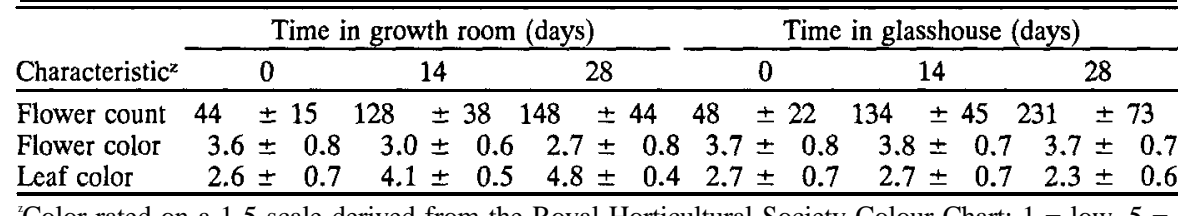

${ }^{2}$ Color rated on a 1-5 scale derived from the Royal Horticultural Society Colour Chart; $1=$ low, $5=$ high color intensity. 
Table 3. Mean squares for the analysis of variance of three characteristics of Exacum affine.

\begin{tabular}{|c|c|c|c|c|c|c|}
\hline \multirow{3}{*}{$\begin{array}{l}\text { Source of } \\
\text { variation }\end{array}$} & \multicolumn{3}{|c|}{ Growth room } & \multicolumn{3}{|c|}{ Glasshouse } \\
\hline & \multicolumn{2}{|c|}{ Flower } & \multirow{2}{*}{$\begin{array}{l}\text { Leaf } \\
\text { color }\end{array}$} & \multicolumn{2}{|c|}{ Flower } & \multirow{2}{*}{$\begin{array}{l}\text { Leaf } \\
\text { color }\end{array}$} \\
\hline & Count & Color & & Count & Color & \\
\hline Block & $24,173^{* *}$ & $1.8^{\mathrm{NS}}$ & $1.9^{\mathrm{NS}}$ & $2,886^{\mathrm{NS}}$ & $2.9^{\mathrm{NS}}$ & $1.6^{\mathrm{NS}}$ \\
\hline Genotype & $16,185^{* *}$ & $9.6^{* *}$ & $1.6^{\mathrm{NS}}$ & $28,982^{* *}$ & $10.1^{* *}$ & $3.2^{\mathrm{Ns}}$ \\
\hline Day & $548,860^{* *}$ & $30.6^{* *}$ & $230 * *$ & $1,506,459 * *$ & $0.7^{\mathrm{NS}}$ & $8.9^{*}$ \\
\hline Linear & $972,504^{* *}$ & $58.7^{* *}$ & $440^{* *}$ & $3,009,437^{* *}$ & $0.1^{\text {NS }}$ & $11.7^{*}$ \\
\hline Lack of fit & $125,216^{* *}$ & $2.4^{\mathrm{NS}}$ & $20.3^{* *}$ & $3,481^{\mathrm{NS}}$ & $1.3^{\mathrm{NS}}$ & $6.1^{\mathrm{Ns}}$ \\
\hline Genotype $\times$ day & $2,049^{\mathrm{NS}}$ & $0.5^{\mathrm{NS}}$ & $0.3^{\mathrm{NS}}$ & $5,733^{\text {NS }}$ & $0.5^{\mathrm{NS}}$ & $0.8^{\mathrm{NS}}$ \\
\hline Experimental error & 4,284 & 1.2 & 1.6 & 12,028 & 1.3 & 2.1 \\
\hline Sampling error & 548 & 0.2 & 0.2 & 1,467 & 0.3 & 0.3 \\
\hline
\end{tabular}

Ns.****Nonsignificant or significant at $P=0.5$, or 0.01 , respectively.

Table 4. Mean percentage change for three characteristics of 15 genotypes of Exacum affine after 28 days of maintenance in the growth room or glasshouse.

\begin{tabular}{|c|c|c|c|c|c|c|}
\hline \multirow[b]{3}{*}{ Genotype } & \multicolumn{3}{|c|}{ Growth room } & \multicolumn{3}{|c|}{ Glasshouse } \\
\hline & \multirow{2}{*}{$\begin{array}{l}\text { Flower } \\
\text { count }\end{array}$} & \multicolumn{2}{|c|}{ Color ${ }^{y}$} & \multirow{2}{*}{$\begin{array}{l}\text { Flower } \\
\text { count }\end{array}$} & \multicolumn{2}{|c|}{ Color ${ }^{y}$} \\
\hline & & Flower & Leaf & & Flower & Leaf \\
\hline & \multicolumn{6}{|c|}{ Change (\%) } \\
\hline Petite & 251 & -30 & 46 & 606 & 4 & -12 \\
\hline $\mathrm{CE}$ & 293 & -13 & 100 & 464 & 0 & -4 \\
\hline Michigan White & 261 & $\ldots$ & 81 & 562 & $\ldots$ & -33 \\
\hline $3057 \mathrm{~A}$ & 190 & -33 & 102 & 398 & -5 & -19 \\
\hline $42 \mathrm{E}$ & 196 & -25 & 102 & 382 & 6 & 0 \\
\hline 3033 & 196 & -17 & 92 & 348 & 0 & -18 \\
\hline Royal Blue & 262 & -37 & 99 & 398 & -15 & 21 \\
\hline $4002 \mathrm{~A}$ & 252 & $\ldots$ & 110 & 354 & -.. & -19 \\
\hline Best Rosa & 327 & -8 & 80 & 563 & 6 & -22 \\
\hline White Champion & 233 & $\ldots$ & 112 & 370 & $\ldots$ & -11 \\
\hline Blue Champion & 323 & -23 & 111 & 377 & 9 & -6 \\
\hline Little Champ & 242 & -15 & 115 & 514 & 9 & -8 \\
\hline $42 \mathrm{Y}$ & 281 & -23 & 108 & 387 & -4 & -8 \\
\hline 505 & 218 & -40 & 79 & 322 & -1 & 25 \\
\hline Blue Chip & 247 & -27 & 104 & 339 & 4 & -10 \\
\hline LSD $(0.05)$ & 92 & 15 & 43 & 158 & 18 & 25 \\
\hline
\end{tabular}

${ }^{7}$ Percentage change $=[$ (value day $28-$ value day $0 /$ value day 0$] \times 100$.

'Rated on a 1 to 5 scale derived from the Royal Horticultural Society Colour Chart (1986); $1=$ low color intensity, 5 = high color intensity.

room was linear (Table 3). Koes et al. (1989) reported that the expression of genes coding for chalcone synthase enzymes in the flavonoid biosynthetic pathway of Petunia hybrida Vilm. are red-light dependent. Further research is needed to determine if a light dependency is responsible for the reduction of color intensity of new flowers when $E$. affine plants are maintained under low irradiance from cool-white fluorescent tubes.

Leaf color improved in the growth room and tended to deteriorate in the glasshouse (Table 2). Most of the increased intensity in leaf color occurred during the first 2 weeks in the low-irradiance environment, which was reflected in a lack of fit to a linear model although further research is necessary to determine the genetic basis for the observed differences. In the glasshouse, CE was the only genotype that was among the five highest ranking genotypes for all three characteristics (increase in flower count, flower color development, leaf color development). After 28 days in the low-irradiance growth room, 'Blue Champion' and $42 \mathrm{Y}$ were among the five highest ranking genotypes for all three characteristics. CE, 'Best Rose', and 'Little Champ' each ranked among the best five genotypes for two of the three characteristics evaluated. Variability for flower bud and flower color development in a low-irradiance environment is present in cultivated $E$. affine germplasm and may permit breeding for improved performance for these characteristics.

\section{Literature Cited}

Harbaugh, B.K. and W.E. Waters. 1979. Evaluation of flowering potted plants under simulated home conditions. HortScience 14:743-745.

Harbaugh, B.K. and W.E. Waters. 1982. Influence of controlled-release fertilizer on Exacum affine Balf. 'Elfin' during production and subsequent simulated home conditions, HortScience 17:605-606.

Irwin, J. 1979. Exacum affine-Tiddlywinks. Ohio Florists Assn. Bul. 600.

Irwin, L. 1984. Exacum. Minn. State Florists Bul. 33:8-9.

Koes, R.E., C.E. Spelt, and J.N.M. Mol. 1989. The chalcone synthase multigene family of Petunia hybrida (V30): differential, light-regulated expression during flower development and UV light induction. Plant Mol. Biol. 12:213225

Larson, R.A. 1981. Commercial production of Exacum. North Carolina Flower Growers Bul. 25.

Nell, T.A. and J.E. Barrett. 1986. Production light level effects on light compensation point, carbon exchange rate and post-production longevity of poinsettias. Acta Hort. 181:257-262.

Royal Horticultural Society color chart, 1986. Royal Hort. Soc., London; in association with the Flower Council of Holland.

Salisbury, F.B. and C.W. Ross. 1978. Plant physiology. 2nd ed. Wadsworth Publishing, Belmont, Calif.

Shafer, B.S. and J.W. Kelly. 1986. The influence of cultivar, price, and longevity on consumer preferences for potted chrysanthemums. HortScience 21:1412-1413.

Williams, S., S. Wolf, and E.J. Holcomb. 1983. Growth and flowering of Exacum affine at three radiant energy levels. HortScience 18:366-367. 